\title{
PENGARUH PENAMBAHAN BAHAN PANGAN LOKAL TERHADAP SIFAT ORGANOLEPTIK DAN KANDUNGAN SERAT SNACK BAR SEBAGAI ALTERNATIF JAJANAN TINGGI SERAT
}

\author{
Marisa Wahyu Ningsih ${ }^{\mathbf{1}}$, Made Darawati ${ }^{\mathbf{*}}$ Dan I Gde Narda Widiada $^{\mathbf{1}}$ \\ ${ }^{1}$ Jurusan Gizi, Poltekkes Kemenkes Mataram \\ J1. Prabu Rangkasari, Sandubaya, Kota Mataram, Nusa Tenggara Barat 83232, Indonesia \\ *Korespondensi : Email: madedarawati12@gmail.com
}

\begin{tabular}{l}
\hline Article Info \\
\hline Article history: \\
Received January $14^{\text {th }}, 2021$ \\
Revised February $21^{\text {th }}, 2021$ \\
Accepte March $25^{\text {th }}, 2021$ \\
\hline
\end{tabular}

\section{Keyword:}

Local food, Fiber content; Organoleptic properties; Snack bar

\section{Keyword:}

Kandungan serat; Pangan local; Sifat organoleptic; Snack bar

\begin{abstract}
Background : Food snacks circulating in the community generally do not have guaranteed security and balanced nutritional content. So that the development of snacks is very important. One food product that is easily developed can be used as a snack or a daily snack that is a snack bar. The development of snack products in the form of snack bars can be made using local food ingredients. This snack bar formulation will then have a high enough fiber content so that it is expected to be an alternative snack food to reduce the incidence of Obesity.
\end{abstract}

Objective : Knowing the effect of adding local food ingredients to the organoleptic properties and fiber content of snack bars as an alternative to high-fiber snacks.

Method: This research is a literature study which summarizes some literature that is relevant to the research theme / topic. Literature is obtained through searches conducted on several internet pages. In this study, the type of data used is secondary data. The literature that was reviewed was first selected according to the inclusion and exclusion criteria.

Results: Of the 11 journals reviewed 2 of them stated there was an effect of adding local food to the organoleptic nature of snack bars. And of the 11 journals reviewed 4 of them had a snack bar formulation with a relatively high fiber content. So that the recommended snack bar formulation research Pratama (2019) as an alternative to high-fiber healthy snacks.

Conclusion: Of the 11 journals reviewed 2 of them stated there was an effect of adding local food to the organoleptic nature and fiber content of snack bars.

\footnotetext{
ABSTRAK

Latar Belakang : Pangan jajanan yang beredar di masyarakat umumnya belum memiliki jaminan kemanan dan kandungan gizi yang seimbang. Sehingga pengembangan pangan jajanan sangat penting. Salah satu produk pangan yang mudah dikembangkan dapat dijadikan camilan maupun jajanan sehari-hari yaitu snack bar. Pengembangan produk camilan berupa snack bar dapat dibuat dengan menggunakan bahan pangan lokal. Formulasi snack bar ini kemudian akan memiliki kandungan serat yang cukup tinggi sehingga diharapakan dapat menjadi makanan camilan alternatif untuk mengurangi kejadian Obesitas.
} 
Tujuan : Mengetahui pengaruh penambahan bahan pangan lokal terhadap sifat organoleptik dan kandungan serat snack bar sebagai alternatif jajanan tinggi serat.

\begin{abstract}
Metode : Penelitian ini adalah sebuah studi literatur yang meringkas beberapa jurnal yang berkaitan dengan tema/topic. Jurnal diperoleh melalui pencarian yang dilakukan di beberapa laman internet. Pada penelelitian ini jenis data yang digunakan adalah data skunder. Jurnal yang dikaji terlebih dahulu diseleksi sesuai dengan kriteria inklusi dan eksklusi. Lalu data yang sudah diperoleh kemudian diolah dan dianalisis secara deskriptif.
\end{abstract}

Hasil : Dari 11 jurnal yang direview 2 diantaranya menyatakan ada pengaruh penambahan bahan pangan lokal terhadap sifat organoleptik snack bar. Dan dari 11 jurnal yang direview 4 diantaranya memiliki formulasi snack bar dengan kandungan serat yang tergolong tinggi. Sehingga direkomendasikan formulasi snack bar penelitian Pratama (2019) sebagai alternatif jajanan sehat tinggi serat.

Kesimpulan : Sisa makanan terbanyak yaitu pada makanan saring dan sisa makanan diet tinggi serat dan rendah garam bersisa

\title{
PENDAHULUAN
}

Pangan jajanan memiliki peran yang penting bagi pertumbuhan seseorang, sebab dapat menyumbangkan energi dan zat gizi yang dibutuhkan untuk pertumbuhan. Permasalahannya, pangan jajanan yang beredar belum semuanya dapat dijamin keamanan maupun kandungan gizinya sehingga perlu mendapatkan perhatian khusus dalam mengembangkan pangan jajanan, sebab secara tidak langsung dapat menjadi salah satu penghambat penting dalam pembangunan sumber daya manusia di Indonesia di masa depan (Paramtmanitya dan Veriani dalam (Rachmayani et al., 2017).

Pola konsumsi pangan jajanan yang berlebihan dapat memberikan dampak negatif yaitu dapat menyebabkan terjadinya kelebihan asupan energi (Rahmad, 2019). Disisi lain juga terjadi peningkatan obesitas yang disebabkan oleh pola konsumsi pangan yang tidak seimbang dan rendahnya aktivitas fisik (Depres, 2014 dalam (Rachmayani et al., 2017)). Kebiasaan ini sering terjadi di masyarakat perkotaan, mereka sering mengkonsumsi makanan siap saji dimana sebagian besar merupakan makanan sumber hewani dan tidak diimbangi dengan makanan sumber nabati sehingga menyebabkan konsumsi serat seseorang menjadi rendah (Knadou, 2009 dalam (Hendrayati, Manjilala and Islamiati, 2019)). Pengembangan pangan jajanan sangat penting karena pangan jajanan adalah salah satu alternaitf untuk memenuhi kebutuhan zat gizi. Dari penelitian yang dilakukan oleh Rahmi dam Muis (2005 dalam (Harikedua, Legi and Sarullah, 2015) didapatkan data bahwa makanan jajanan memberikan kontribusi yaitu 22,9\% dan 15,9\% terhadap total asupan energi dan protein seseorang.

Salah usaha yang dapat dilakukan untuk mencegah masalah obesitas adalah dengan memberikan edukasi dan memperbaiki kandungan pangan jajanan yang beredar, yaitu dengan pendekatan inovasi pangan tinggi serat (Kurdanti et al., 2015 dalam (Rachmayani et al., 2017)). Salah satu produk pangan yang mudah dikembangkan dapat dijadikan camilan maupun jajanan sehari-hari yaitu snack bar.

Snack bar merupakan salah satu cemilan atau kudapan yang digemari oleh semua kalangan masyarakat. Selain itu, bentuk snack bar mudah dan praktis untuk dibawa tanpa membutuhkan kondisi khusus seperti harus tetap berada dalam kondisi hangat atau dingin. Pengembangan produk camilan berupa snack bar dapat dibuat dengan menggunakan bahan pangan lokal. Formulasi snack bar ini kemudian akan memiliki kandungan serat yang cukup tinggi sehingga diharapakan dapat menjadi makanan camilan alternatif untuk mengurangi kejadian Obesitas (Adiari et al., 2017).

Pada penelitian (Rachmayani et al., 2017), yiatu penelitian formulasi snack bar tinggi serat berbahan dasar tepung ampas tahu dan tepung ubi ungu didapatkan formula terbaik yaitu dengan persentase penambahan 
tepung ampas tahu sebesar 20\% dengan perbandingan tepung ubi jalar ungu dan tepung maizena 1:2. Pada penelitian lainnya yaitu penelitian yang dilakukan oleh (Pricilya, W and Andriani, 2015) yang meneliti formulasi snack bar kacang hijau dan bekatul diperoleh formula terbaik dengan perbandingan kacang hijau dan bekatul yaitu $60 \%: 40 \%$.

Pada formulasi snack bar (Rachmayani et al., 2017) tepung ampas tahu dan tepung ubi jalar ungu dihasilkan snack bar yang kandungan seratnya cukup tinggi namun warna snack bar yang dihasikan kurang menarik. Pada formulasi snack bar (Pricilya, W and Andriani, 2015) kacang hijau dan bekatul dihasilkan snack bar yang mempunyai kandungan serat yang cukup tinggi jika dibandingkan dengan produk snack bar komersial dengan warna snack bar yang dihasilkan cukup menarik.

Alternatif pangan lokal tinggi serat untuk formulasi snack bar tinggi serat berdasarkan jurnal-jurnal di atas yaitu diantaranya bisa menggunakan bahan-bahan antara lain tepung ampas tahu, kacang hijau, dan bekatul. Ampas tahu atau okara (Martos dan Ruperez, 2009 dalam (Rachmayani et al., 2017)) merupakan residu berserat yang diperoleh dari pengolahan susu kedelai dan tahu, yang masih mengandung 20-27\% protein (Katyama dan Wilson, 2008 (Rachmayani et al., 2017)).

Kacang hijau memiliki kandungan serat sebesar 7,5/100 gram, sehingga bisa memenuhi kebutuhan serat sebesar 20\% sehari (Persagi, 2012 dalam (Pricilya, W and Andriani, 2015)). Bekatul (Rice polish) adalah hasil proses penggilingan padi yang berasal dari lapisan luar beras. Keberadaan bekatul di Indonesia sangat melimpah, tetapi penggunaan bekatul untuk makanan manusia masih terbatas. Menurut USDA Nutrition (Dalam (Pricilya, W and Andriani, 2015)), bekatul memiliki serat sebesar 21/100 gram.

Konsumsi snack bar formula modifikasi dari bahan pangan lokal ini diharapkan dapat mengurangi kejadian obesitas. Snack bar ini dianjurkan untuk dikonsumsi dengan tujuan mengatasi masalah obesitas pada dewasa $>18$ tahun, dimana disarankan dikonsumsi pada jam makan selingan yaitu saat selingan pagi dan selingan sore.

Menurut penjabaran di atas maka dilaksanakan studi literatur mengenai pengaruh penambahan bahan pangan lokal terhadap sifat organoleptik dan kandungan serat snack bar sebagai alternatif jajanan tinggi serat.

\section{METODE PENELITIAN}

Penelitian ini adalah sebuah studi literatur yang meringkas beberapa jurnal yang berhubungan dengan tema/topic penelitian, seperti jurnal penelitian, review jurnal, dan data yang berkaitan dengan tema/ topic penelitian. Literatur diperoleh melalui pencarian atau indentifikasi yang dilakukan di beberapa laman internet antara lain dari google search, google scholar dan Directory of Open Access Journals dan diperoleh literatur sebanyak 27 literatur. Kata kunci yang digunkan dalam pencarian literatur antara lain: Formula snack bar tinggi serat, formula snack bar tinggi serat pada obesitas. Literatur yang sudah diperoleh kemudian di skrining berdasarkan ketersediaan literatur dalam bentuk full text, dan dilihat dari tahun terbit yaitu literatur yang diambil merupakan lietratur yang diterbitkan dari tahun 2015 sampai tahun 2020, dimana literatur yang tersisa menjadi 14 literatur. Seluruh literatur lalu diseleksi kembali menggunakan kriteria inklusi dan eksklusi sehingga diperoleh hasil akhir dari literatur sebanyak 11 literatur.

Literatur memiliki kesesuain topik dengan rencana penelitian yaitu formulasi snack bar tinggi serat.

Literature berupa studi kuantitatif ataupun kualitatif atau mixed method.

Literatur dalam bentuk full text.

Literatur dipublikasikan antara tahun 2015 samapi dengan 2020.

\section{HASIL DAN PEMBAHASAN PENELITIAN}

Pengaruh Penambahan Bahan Pangan Lokal terhadap sifat Organoleptik Snack Bar Sebagai Alternatif Jajanan Tinggi Serat

\section{Warna}

Dengan penambahan tepung ampas tahu dan tepung ubi ungu (Rachmayani et al., 2017) serta tepung rumput laut, tepung pisang dan tepung mocaf (Kusumaningrum and Rahayu, 2018) pada formulasi snack bar, maka dihasilkan snack bar dengan warna putih pucat. Warna tepung yang dihasilkan dari masing-masing bahan yang umumnya berwarna putih menutupi warna lain yang muncul dari bahan minor sehingga mempengaruhi warna snack bar yang dihasilkan. Dimana warna suatu bahan pangan formulasi berasal dari warna almiah 
bahan penyusun suatu pangan dan juga bisa berasal dari warna yang terbentuk selama proses pengolahan (Soeparyo, Rawung and Assa, 2018).

Penelitian tentang formulasi snack bar yang dilakukan oleh (Pricilya, W and Andriani, 2015), (Indrawan, Sevelin and Ningrum, 2018), (Arwin, Tamrin, Rahman Baco, 2018), (Pratiwi, Sari and Tifauzah, 2017), (Siregar, Rahmayuni and Noviar, 2017), dan (Pratama, 2019) dengan bahan dasar kacang hijau dan bekatul, tepung ampas kelapa dan tepung kedelai, tepung beras merah dan kacang merah, tepung cassava dan tepung kacang merah, tepung kacang merah dan buah salak dan terakhir tepung mocaf dan tepung kacang merah menghasilkan snack bar dengan warna coklat muda hingga coklat tua. Warna kecoklatan yang dihasilkan ini dipengaruhi oleh pigmen yang dikandung oleh kacang-kacangan yang digunakan dalam pembuatan snack bar yaitu pigmen antosianin dan ditambah dengan reaksi karamelisasi dari gula dan madu yang dipanaskan dan juga reaksi maillard yang timbul akibat pemanggangan (Pricilya, W and Andriani, 2015).

Pada penelitian tentang makanan selingan tinggi serat dan rendah indeks glikemik untuk penderita diabetes melitus tipe 2 (Marlina et al., 2019) diperoleh snack bar dengan warna hitam keunguan. Hal ini dipengaruhi oleh kandungan antosianin dengan intensitas tinggi pada beras hitam sehingga menghasilkan warna ungu pekat mendekati hitam (Marlina et al., 2019).

Andriani, Ansharullah and Asyik (2018) melakukan penelitian tentang Karakteristik organoleptik dan nilai gizi snack bar berbasis tepung beras merah (oryza nivara) dan tepung jagung (zea mays l) sebagai makanan selingan tinggi serat menghasilkan snack bar dengan warna merah gelap hingga terang. Hal ini dipengaruhi oleh kandungan antosianin pada kacang merah, bila variasi pencampuran semakin besar maka warna yang dihasikan juga akan semakin gelap (Dewi at al., 2016 dalam (Andriani, Ansharullah and Asyik, 2018)).

\section{Aroma}

Pada penelitian yang dilakukan oleh Rachmayani et al., (2017) yaitu mengenai snack bar tinggi serat berbasis tepung ampas tahu dan tepung ubi ungu diperoleh snack bar dengan aroma khas harum ubi jalar ungu dan blueberry. Akan tetapi aroma ini akan semakin tertutupi oleh aroma tepung ampas tahu seiring dengan bertambahnya penambahan tepung ampas tahu pada formulasi snack bar (Rachmayani et al., 2017).

Snack bar dengan bahan dasar kacang hijau dan bekatul yang diteliti oleh oleh Pricilya, W and Andriani (2015) yaitu terkait daya terima dan proporsi bahan utama snack bar terhadap kandungan seratnya diperoleh snack bar dengan karakteristik aroma khas kacang hijau. Hal ini karena tepung kacang hijau yang digunakan dalam formulasi snack bar memiliki ciri aroma yang langu sehingga pemakaian persentase tepung kacang hijau yang terus meningkat akan mempengaruhi aroma produk yang dihasilkan (Astawan, 2008 dalam (Pricilya, W and Andriani, 2015)).

Pada penelitian Indrawan, Sevelin and Ningrum (2018) yaitu tentang pembuatan snack bar tinggi serat berbahan dasar tepung ampas kelapa dan tepung kedelai diperoleh snack bar dengan aroma ampas kelapa yang khas. Akan tetapi aroma ini dapat berkurang karena sebelum proses pengeringan dilakukan proses blanching selama 10 menit, dan penggunaan bahan lain seperti selai dan kacang mete (Indrawan, Sevelin and Ningrum, 2018).

Penelitian lainnya yang dilakukan oleh Arwin, Tamrin, Rahman Baco (2018) yaitu tentang pengkajian penilaian organoleptik dan nilai gizi snack bar berbasis tepung beras merah dan kacang merah sebagai makanan selingan yang berserat tinggi menghasilkan snack bar dengan aroma langu khas bahan utama. Hal ini dipengaruhi oleh aroma langu khas dari kedua bahan utam yaitu tepung beras merah dan kacang merah (Arwin, Tamrin, Rahman Baco, 2018).

Pratama (2019) melakukan penelitian tentang daya terima snack bar rendah energi tinggi serat berbahan dasar tepung mocaf dan tepung kacang merah dimana menghasilkan snack bar dengan aroma khas oat dan aroma sedikit langu. Aroma langu yang dimiliki kacang merah mempengaruhi aroma pada produk yang dihasilkan, aroma tersebut berasal dari enzim lipoksigase yang secara alami ditemukan dalam kacang-kacangan, sehingga dengan banyaknya persentase tepung kacang merah yang ditambahkan maka produk yang dihasilkan akan semakin beraroma langu khas kacang merah (Pratama, 2019). 
Selanjutnya penelitian yang dilakukan oleh Pratiwi, Sari and Tifauzah (2017) tentang Analisis kandungan protein dan kandungan serat pada snack bars berbahan campuran tepung cassava dan tepung kacang merah diperoleh snack bar dengan aroma khas kue kering. Proses pemanggangan dan bahan-bahan lain yang digunakan dalam adonan snack bar hampir sama dengan bahan pembuatan kue kering. Hal ini menyebabkan ketiga perlakuan penambahan campuran tepung cassava dan tepung kacang merah memiliki aroma yang sama yaitu aroma khas kue kering (Pratiwi, Sari and Tifauzah, 2017).

Kusumaningrum and Rahayu (2018) melakukan penelitian tentang Formulasi snack bar tinggi kalium dan tinggi serat berbahan dasar rumput laut, pisang kepok, dan mocaf sebagai snack alternatif bagi penderita hipertensi dihasilkan snack bar dengan aroma harum karamel. Hal ini dipengaruhi oleh aroma yang terbentuk pada saat pemanggangan produk, hal ini berarti penambahan isi coklat dan ceri meberikan mutu aroma yang sama di setiap produk (Kusumaningrum and Rahayu, 2018).

Pada penelitian tentang makanan selingan tinggi serat dan rendah indeks glikemik untuk penderita diabetes melitus tipe 2 (Marlina et al., 2019) diperoleh snack bar dengan aroma beras hitam yang sangat terasa. Hal ini dipengaruhi oleh pada formulasi snack bar penambahan beras hitam lebih banyak dibandingkan kedelai hitam oleh karen itu aroma yang mendominasi adalah aroma beras hitam (Marlina et al., 2019)).

Andriani, Ansharullah and Asyik (2018) melakukan penelitian tentang Karakteristik organoleptik dan nilai gizi snack bar berbahan tepung beras merah (oryza nivara) dan tepung jagung (zea mays l) sebagai makanan selingan tinggi serat menghasilkan snack bar dengan aroma khas jagung. Hal ini dipengaruhi oleh penambahan tepung jagung yang bisa menutupi aroma khas dari tepung beras merah. Hal ini sejalan dengan penelitian Fatkurahman et al., (2012 dalam (Andriani, Ansharullah and Asyik, 2018)) menyatakan bahwa semakin tinggi konsentrasi tepung jagung yang digunakan pada pembuatan cookies, maka semakin tinggi pula kesukaan panelis terhadap karakteristik aroma cookies.

Terakhir pada penelitian yang dilakukan oleh (Siregar, Rahmayuni and Noviar, 2017) tentang Penggunaan tepung kacang merah dan salak padang sidimpuan (Salacca Sumatrana R) dalam pembuatan snack bar diperoleh snack bar dengan aroma buah salak hingga tepung kacang merah. Hal ini dipengaruhi oleh komposisi penambahan tepung kacang merah dan buah salak dalam formulasi snack bar. Dimana semakin tinggi penambahan tepung kacang merah maka snack bar akan beraroma khas kacang merah dan begitu juga sebaliknya. Aroma yang dihasilkan snack bar dipengaruhi oleh berbagai komponen bahan lain dalam adonan seperti margarin, gula dan telur (Siregar, Rahmayuni and Noviar, 2017).

\section{Rasa}

Pada penelitian yang dilakukan oleh (Rachmayani et al., 2017) yaitu tentang snack bar tinggi serat berbasis tepung ampas tahu dan tepung ubi ungu diperoleh snack bar dengan rasa khas tepung ampas tahu. Hal ini dipengaruhi oleh bahan utama yang digunakan dalam pembuatan snack bar yaitu tepung ampas tahu (Rachmayani et al., 2017).

Snack bar dengan bahan dasar kacang hijau dan bekatul yang diteliti oleh oleh Pricilya, W and Andriani (2015) yaitu terkait daya terima dan proporsi bahan utama snack bar terhadap kandungan seratnya diperoleh snack bar dengan karakteristik rasa yang disukai. Hal ini dipengaruhi oleh perbandingan komposisi kacang hijau dan bekatul dalam formulasi snack bar hampir seimbang sehingga menghasilkan rasa yang disukai (Pricilya, W and Andriani, 2015). Dimana menurut Nataliningsih (2009 dalam (Pricilya, W and Andriani, 2015)) rasa bekatul yang dibuat menjadi makanan akan terasa kurang enak dan agak pahit akan tetapi karena adanya penambahan komposisi kacang hijau dan bahan lain dalam snack bar dengan formulasi yang tepat maka snack bar yang dihasilkan mempunyai rasa yang disukai.

Pada penelitian Indrawan, Sevelin and Ningrum (2018) yaitu tentang pembuatan snack bar tinggi serat berbahan dasar tepung ampas kelapa dan tepung kedelai diperoleh snack bar dengan rasa khas ampas kelapa. Akan tetapi rasa khas ampas kelapa bisa berkurang seiring dengan ditambahkannya bahan lain seperti selai dan madu, tetapi pada produk snack bar yang dihasilkan tetap terdapat rasa khas ampas kelapa (Indrawan, Sevelin and Ningrum, 2018). 
Pada penelitian tentang makanan selingan tinggi serat dan rendah indeks glikemik untuk penderita diabetes melitus tipe 2 (Marlina et al., 2019) diperoleh snack bar dengan rasa manis yang tidak merata. Hal ini dipengaruhi oleh pengadukan gula yang tidak merata (Marlina et al., 2019).

Penelitian lainnya yang dilakukan oleh (Arwin, Tamrin, Rahman Baco, 2018) yaitu tentang kajian penilaian organoleptik dan nilai gizi snack bar berbahan tepung beras merah dan kacang merah sebagai makanan selingan yang berserat tinggi menghasilkan snack bar dengan rasa manis yang tidak berlebihan. Hal ini menunjukkan bahwa dengan meningkatnya komposisi tepung beras merah yang ditambahkan maka snack bar akan lebih berasa khas beras merah adapun dengan penambahan kacang merah yang lebih banyak maka snack bar akan lebih berasa khas kacang merah (Arwin, Tamrin, Rahman Baco, 2018).

Pratama (2019) melakukan penelitian tentang daya terima snack bar rendah energi tinggi serat berbahan dasar tepung mocaf dan tepung kacang merah dimana menghasilkan snack bar dengan rasa yang berbeda untuk setiap perlakuan. Hal ini dipengaruhi oleh perbedaan variasi penambahan tepung kacang merah dan tepung mocaf pada setiap perlakuan (Pratama, 2019).

Andriani, Ansharullah and Asyik (2018) melakukan penelitian tentang Karakteristik organoleptik dan nilai gizi snack bar berbahan tepung beras merah (oryza nivara) dan tepung jagung (zea mays l) sebagai makanan selingan tinggi serat menghasilkan snack bar dengan rasa khas jagung. Hal ini dipengaruhi oleh penambahan tepung jagung yang cukup banyak dalam formulasi snack bar. Hal ini sesuai dengan penelitian Rahma et al., (2017 dalam (Andriani, Ansharullah and Asyik, 2018)) dimana semakin besar persentase penambahan tepung jagung maka rasa rori tawar yang dihasilkan berasa jagung.

Selanjutnya penelitian yang dilakukan oleh Pratiwi, Sari and Tifauzah (2017) tentang Analisis kadar protein dan kadar serat pada snack bars berbahan campuran tepung cassava dan tepung kacang merah diperoleh snack bar dengan rasa khas kue kering. Hal ini dikarenakan komposisi tepung singkong lebih banyak dibandingkan dengan tepung kacang merah sehingga rasa langu dari tepung kacang merah sedikit berkurang (Pratiwi, Sari and Tifauzah, 2017).

Kusumaningrum and Rahayu (2018) melakukan penelitian tentang Formulasi snack bar tinggi kalium dan tinggi serat berbahan dasar rumput laut, pisang kepok, dan mocaf sebagai snack alternatif bagi penderita hipertensi dihasilkan snack bar dengan rasa khas kue kering. Hal ini dikarenakan komposisi dari masing masing bahan tidak ada yang terlalu menonjol sehingga tidak ada yang mendominasi dari rasa yang dihasilkan oleh snack bar, maka dihasilkanlah rasa khas kue kering (Kusumaningrum and Rahayu, 2018).

Terakhir pada penelitian yang dilakukan oleh Siregar, Rahmayuni and Noviar (2017) tentang Penggunaan tepung kacang merah dan salak padang sidimpuan (Salacca Sumatrana R) dalam formulasi snack bar diperoleh snack bar dengan rasa buah salak hingga kacang merah. Hal ini dipengaruhi oleh komposisi penambahan tepung kacang merah dan buah salak dalam formulasi snack bar. Dimana semakin banyak tepung kacang merah yang ditambahkan maka snack bar akan berasa khas kacang merah dan begitu juga sebaliknya. Rasa snack bar yang dihasilkan juga dipengaruhi oleh bahan tambahan yang digunakan seperti gula, garam dan maltodekstrin. Menurut Winarno (2008 dalam (Siregar, Rahmayuni and Noviar, 2017)) gula dan garam berberan dalam pengolahan makanan yang berfungsi meningkatkan citarasa, aroma, memperbaiki sifat fisik dan sebagai pengawet.

\section{Tekstur}

Pada penelitian yang dilakukan oleh Rachmayani et al., (2017) yaitu tentang snack bar tinggi serat berbasis tepung ampas tahu dan tepung ubi ungu diperoleh snack bar dengan tekstur beremah dan kasar. Hal ini dipengaruhi oleh penambahan tepung ampas tahu pada pembuatan snack bar dimana semakin banyak tepung ampas tahu yang ditambahkan dalam formulasi snack bar maka tekstur snack bar akan menjadi beremah dan kasar sehingga kurang disukai (Rachmayani et al., 2017).

Pada penelitian Pricilya, W and Andriani (2015) dan Pratama (2019) tentang formulasi snack bar berbahan dasar kacang hijau dan bekatul serta tepung mocaf dan tepung kacang merah dihasilkan snack bar dengan tekstur tidak begitu menyatu dan rapuh. Hal ini dipengaruhi oleh kurangnya homogen saat pencampuran bahan. Selama pembentukan makanan waktu pencampuran harus diperhatikan untuk menghasilkan produk 
yang homogen dengan tesktur yang sesuai, sehingga waktu yang diperlukan untuk proses homogenasi lumayan lama (Faridah, 2008 dalam (Pratama, 2019)).

Snack bar dengan bahan dasar tepung ampas kelapa dan tepung kedali (Indrawan, Sevelin and Ningrum, 2018), tepung beras merah dan kacang merah (Arwin, Tamrin, Rahman Baco, 2018), tepung rumput laut, tepung pisang dan tepung mocaf (Kusumaningrum and Rahayu, 2018) dan terakhir tepung beras hitam dan tepung kedelai hitam (Marlina et al., 2019) menghasilkan snack bar dengan tesktur padat. Hal ini dipengaruhi oleh bahan baku yang digunakan terutama penambahan bahan binder (selai, madu dan telur) yang dapat mengikat bahan baku sehingga tesktur snack bar yang didapat adalah padat (Indrawan, 2018). Selin itu tesktur pada pada snack bar dipengaruhi oleh kadar air dari bahan baku penyusunnya. Semakin tinggi kadar air yang dikandung bahan baku maka snack bar yang dihasilkan akan rapuh dan tidak keras dan semakin sedikit kadar air yang dikandung bahan baku maka snack bar yang dihasilkan akan bertesktur padat dan keras (Arwin, Tamrin, Rahman Baco, 2018).

Selanjutnya penelitian yang dilakukan oleh Pratiwi, Sari and Tifauzah (2017) tentang Analisis kadar protein dan kadar serat pada snack bars berbahan campuran tepung cassava dan tepung kacang merah diperoleh snack bar dengan tekstur agak kasar. Granola yang terdapat dalam adonan snack bar mempengaruhi tekstur dari snack bar itu sendiri sehingga menjadi agak kasar. Granola tersusun dari buah-buah kering seperti kismis dan pisang, oats serta biji-bijian. Produk snack bar yang dihasilkan sama karena bahan utama yang digunakan sama yaitu berbentuk tepung dan bahan penunjang lainnya pun sama (Pratiwi, Sari and Tifauzah, 2017).

Andriani, Ansharullah and Asyik (2018) melakukan penelitian tentang Karakteristik organoleptik dan nilai gizi snack bar berbasis tepung beras merah (oryza nivara) dan tepung jagung (zea mays 1) sebagai makanan selingan tinggi serat menghasilkan snack bar dengan tekstur keras. Hal ini dipengaruhi oleh penambahan tepung jagung yang cukup banyak pada formulasi snack bar, hal ini sejalan dengan penelitian Ramadhani (2012 dalam (Andriani, Ansharullah and Asyik, 2018) mengatakan bahwa semakin banyak tepung jagung yang digunakan maka tesktur produk yang dihasilkan akan semakin keras.

Terakhir pada penelitian yang dilakukan oleh Siregar, Rahmayuni and Noviar (2017) tentang Pnggunaan tepung kacang merah dan salak padang sidimpuan (Salacca Sumatrana R) dalam pembuatan snack bar diperoleh snack bar dengan tekstur lembut padat hingga kasar padat. Tekstur yang berbeda pada snack bar yang dihasilkan dipengaruhi oleh perbedaan komposisi tepung kacang merah dan buah salak yang ditambahkan. Tekstur snack bar yang dihasilkan lebih padat dan kasar pada penambahan tepung kacang merah lebih banyak dan tekstur snack bar yang dihasilkan lebih padat lembut pada penambahan buah salak lebih banyak. (Siregar, Rahmayuni and Noviar, 2017).

Formulasi snack bar dengan penambahan tepung beras merah dan tepung jagung serta tepung kacang merah dan buah salak berpengaruh nyata terhadap sifat organoleptik snack bar yang dihasilkan yaitu pada formulasi snack bar Andriani, Ansharullah and Asyik (2018) tentang Karakteristik organoleptik dan nilai gizi snack bar berbasis tepung beras merah (oryza nivara) dan tepung jagung (zea mays 1) sebagai makanan selingan tinggi serat. Dan formulasi snack bar oleh Siregar, Rahmayuni and Noviar (2017) tentang Pemanfaatan tepung kacang merah dan salak padang sidimpuan (Salacca Sumatrana R) dalam pembuatan snack bar.

\section{Kandungan Serat Snack Bar Dengan Penambahan Bahan Pangan Lokal Sebagai Alternatif Jajanan Tinggi Serat}

Pada penelitian Rachmayani et al., (2017) diperoleh kandungan serat snack bar dengan berbahan dasar pangan lokal tepung ampas tahu dan tepung ubi ungu yaitu sebesar 13,87\%. Denga formulasi terbaik yaitu persentase penambahan tepung ampas tahu $20 \%$ dan perbandingan tepung ubi jalar ungu dengan tepung maizena 1:2. Jika dibandingkan dengan kandungan serat pada SNI cookies yaitu maksimal 0,5\% (BSN, 1992) dan kebutuhan serat harian untuk satu kali selingan pada dewasa >18 tahun menurut AKG 2019 yaitu 10\% maka kandungan serat pada snack bar penelitian Rachmayani et al., (2017) termasuk tergolong tinggi berdasarkan kandungan serat pada SNI cookies dan sudah memenuhi kecukupan serat makanan selingan pada dewasa.

Pada penelitian yang dilakukan oleh (Pricilya, W and Andriani, 2015) terkait formulasi snack bar kacang hijau dan bekatul dihasilkan snack bar dengan kandungan serat 7,92\%. Dimana formulasi terbaik adalah pada formula F3 dengan perbandingan 60\% kacang hijau dan $40 \%$ bekatul. Jika dibandingkan dengan kandungan 
serat pada SNI cookies yaitu maksimal 0,5\% (BSN, 1992) dan kebutuhan serat harian untuk satu kali selingan pada dewasa >18 tahun menurut AKG 2019 yaitu 10\% maka kandungan serat pada snack bar penelitian (Pricilya, W and Andriani, 2015) tergolong tinggi berdasarkan standar serat pada SNI cookies tetapi belum bisa memenuhi kecukupan serat makanan selingan pada dewasa.

Selanjutnya pada penelitian Indrawan, Sevelin and Ningrum (2018) yang meneliti formulasi snack bar berbahan dasar tepung ampas kelapa dan tepung kedelai diperoleh hasil snack bar dengan kandungan serat 2,59\%. Dimana formulasi terbaik snack bar adalah formulasi F1 yaitu perbandingan tepung ampas kelapa dengan tepung kedelai adalah 15:85. Jika dibandingkan dengan kandungan serat pada SNI cookies yaitu maksimal 0,5\% (BSN, 1992) dan kebutuhan serat harian untuk satu kali selingan pada dewasa $>18$ tahun menurut AKG 2019 yaitu 10\% maka kandungan serat pada snack bar penelitian Indrawan, Sevelin and Ningrum (2018) tergolong tinggi berdasarkan standar serat pada SNI cookies namun belum bisa memenuhi kecukupan serat makanan selingan pada dewasa.

Pada penelitian lainnya yang dilakukan oleh Arwin, Tamrin, Rahman Baco (2018) yang meneliti formulasi snack bar berbasi tepung beras merah dan kacang merah dihasilkan snack bar dengan kandungan serat 4,4\%. Dimana formulasi terbaik adalah perlakuan W4 berdasarkan hasil penilaian organoleptik dengan perbandingan tepung beras merah $60 \mathrm{~g}$ : kacang merah $40 \mathrm{~g}$. Jika dibandingkan dengan kandungan serat pada SNI cookies yaitu maksimal 0,5\% (BSN, 1992) dan kebutuhan serat harian untuk satu kali selingan pada dewasa >18 tahun menurut AKG 2019 yaitu 10\% maka kandungan serat pada snack bar penelitian Arwin, Tamrin, Rahman Baco (2018) tergolong tinggi berdasarkan standar serat pada SNI cookies namun belum bisa memenuhi kecukupan serat makanan selingan pada dewasa.

Adapun pada penelitian Pratama (2019) terkait formulasi snack bar berbahan dasar tepung mocaf dan tepung kacang merah diperoleh snack bar dengan kandungan serat 19,27\%. Dimana formula terbaik adalah formula 3 dengan jumlah tepung campuran yang ditambahkan yaitu 13,5 g. Jika dibandingkan dengan kandungan serat pada SNI cookies yaitu maksimal 0,5\% (BSN, 1992) dan kebutuhan serat harian pada dewasa $>18$ tahun menurut AKG 2019 yaitu 10\% maka kandungan serat pada snack bar penelitian Pratama (2019) tergolong tinggi berdasarkan standar serat pada SNI cookies dan sudah bisa memenuhi kecukupan serat makanan selingan pada dewasa.

Pada penelitian lain terkait formulasi snack bar tepung beras merah dan tepung jagung (Andriani, Ansharullah and Asyik, 2018) diperoleh hasil snack bar dengan kandungan serat 3,57 \%. Dimana formulasi terbaik snack bar adalah perlakuan S4 (tepung beras merah 60\% : tepung jagung 60\%). Jika dibandingkan dengan kandungan serat pada SNI cookies yaitu maksimal 0,5\% (BSN, 1992) dan kebutuhan serat harian untuk satu kali selingan pada dewasa >18 tahun menurut AKG 2019 yaitu 10\% maka kandungan serat pada snack bar penelitian (Andriani, Ansharullah and Asyik, 2018) tergolong tinggi berdasarkan standar serat pada SNI cookies namun belum bisa memenuhi kecukupan serat makanan selingan pada dewasa.

Snack bar dengan bahan dasar tepung cassava dan tepung kacang merah yang formulasinya diteliti oleh Pratiwi, Sari and Tifauzah (2017) dihasilkan snack bar dengan kandungan serat 13,9\%. Dimana snack bar formulasi terbaik adalah sanck bar dengan perbandingan tepung cassava : tepung kacang merah 80\%:20\%. Jika dibandingkan dengan kandungan serat pada SNI cookies yaitu maksimal 0,5\% (BSN, 1992) dan kebutuhan serat harian untuk satu kali selingan pada dewasa >18 tahun menurut AKG 2019 yaitu 10\% maka kandungan serat pada snack bar penelitian Pratiwi (2017) tergolong tinggi berdasarkan standar serat pada SNI cookies dan sudah bisa memenuhi kecukupan serat makanan selingan pada dewasa.

Adapun kandungan serat dari snack bar berbahan dasar tepung kacang merah dan buah salak (Siregar, Rahmayuni and Noviar, 2017) adalah sebesar 8,57\%. Dengan formulasi terbaik snack bar adalah perlakuan KS4 yaitu tepung kacang merah $40 \%$ dan buah salak 60\%. Jika dibandingkan dengan kandungan serat pada SNI cookies yaitu maksimal $0,5 \%$ (BSN, 1992) dan kebutuhan serat harian untuk satu kali selingan pada dewasa >18 tahun menurut AKG 2019 yaitu 10\% maka kandungan serat pada snack bar penelitian Siregar, Rahmayuni and Noviar (2017) tergolong tinggi berdasarkan standar serat SNI cookies namun belum bisa memenuhi kecukupan serat makanan selingan pada dewasa.

Selanjutnya diperoleh hasil snack bar dengan kandungan serat 8,84 \% berbahan dasar tepung rumput lau, tepung pisang kepok dan tepung mocaf yang diteliti formulasinya oleh Kusumaningrum and Rahayu (2018). 
Dimana formulasi snack bar terpilih adalah perlakuan F3 (tepung pisang 31,25 g, tepung mocaf 31,25 g dan tepung rumput laut $31,25 \mathrm{~g}$ ). Jika dibandingkan dengan kandungan serat pada SNI cookies yaitu maksimal $0,5 \%$ (BSN, 1992) dan kebutuhan serat harian untuk satu kali selingan pada dewasa $>18$ tahun menurut AKG 2019 yaitu 10\% maka kandungan serat pada snack bar penelitian Kusumaningrum and Rahayu (2018) tergolong tinggi berdasarkan standar serat pada SNI cookies namun belum bisa memenuhi kecukupan serat makanan selingan pada dewasa.

Selanjutnya snack bar dengan bahan dasar tepung okara dan tepung beras hitam (Adiari et al., 2017) memiliki kandungan serat sebesar 15,58\%. Dimana perlakuan terbaik snack bar adalah perlakuan 1 (tepung okara $10 \mathrm{~g}$ dan tepung beras hitam $5 \mathrm{~g}$ ). Jika dibandingkan dengan kandungan serat pada SNI cookies yaitu maksimal 0,5\% (BSN, 1992) dan kebutuhan serat harian untuk satu kali selingan pada dewasa $>18$ tahun menurut AKG 2019 yaitu 10\% maka kandungan serat pada snack bar penelitian Adiari et al., (2017) tergolong tinggi berdasarkan standar serat SNI cookies dan sudah bisa memenuhi kecukupan serat makanan selingan pada dewasa.

Terakhir formulasi snack bar berbahan dasar tepung beras hitam dan tepung kedelai hitam yang diteliti oleh Marlina et al., (2019) menghasilkan snack bar kandungan serat 5,51\%. Dimana formulasi snack bar terpilih adalah formula F3 (80\% tepung beras hitam : $20 \%$ tepung kedelai hitam). Jika dibandingkan dengan kandungan serat pada SNI cookies yaitu maksimal 0,5\% (BSN, 1992) dan kebutuhan serat harian pada dewasa >18 tahun menurut AKG 2019 yaitu 10\% maka kandungan serat pada snack bar penelitian Marliana, dkk (2019) tergolong tinggi berdasarkan standar serat pada SNI cookies namun belum bisa memenuhi kecukupan serat makanan selingan pada dewasa.

Beberapa formulasi snack bar yang diuraikan di atas memiliki kandungan serat yang tergolong tinggi dan sudaah bisa memnuhi kebutuhan serat untuk selingan pada dewasa sesuai dengan yang diharapkan akan tetapi penerimaan snack bar- snack bar tersebut berbeda-beda tergantung sifat fisik yang dihasilkan yaitu dari karakteristik warna, aroma, rasa dan teskturnya.

Penelitian Rachmayani et al., (2017) menghasilkan snack bar dengan warna putih pucat dan bertesktur beremah kasar yang kurang disukai akan tetapi kandungan sertanya tergolong tinggi yaitu dengan kandungan serat $13,87 \%$ berbahan dasar pangan lokal tepung ampas tahu dan tepung ubi ungu.

Adapun pada penelitian (Pratama, 2019) terkait formulasi snack bar berbahan dasar tepung mocaf dan tepung kacang merah diperoleh snack bar dengan warna merah, tesktur rapuh dan tidak melekat serta aroma khas oat dengan sedikit langu yang kandungan seratnya 19,27\% dimana termasuk tergolong tinggi.

Snack bar dengan bahan dasar tepung cassava dan tepung kacang merah yang formulasinya diteliti oleh Pratiwi, Sari and Tifauzah (2017) dihasilkan snack bar dengan warna coklat muda hingga coklat tua, aroma khas kue kering, rasa khas kue kring dengan tambahan langu dari bahan yang kurang disukai, serta tekstur agak keras hingga keras dengan kandungan serat 13,7\% yang tergolong tinggi.

Terakhir formulasi snack bar berbahan dasar tepung okara dan tepung beras hitam oleh (Adiari et al., 2017) menghasilkan snack bar dengan rasa manis yang berasal dari gula aren serta aroma yang khas dari tepung okara dengan tekstur yang masih agak kasar dengan kandungan serat 15,8\%.

\section{Rekomendasi Formulasi Terbaik dari Sanck Bar Dengan Penambahan Bahan Pangan Lokal Sebagai Alternatif Jajanan Tinggi Serat}

Berdasarkan hasil uraian terkait kandungan serat pada beberapa formulasi snack bar dari beberapa jurnal yang sudah direview maka diperoleh snack bar dengan kandungan serat yang tergolong tinggi jika dibandingkan dengan standar kandungan serat SNI cookies dan sudah memenuhi kecukupan serat untuk selingan pada dewasa adalah sebanyak 4 penelitian dari total 11 hasil penelitian yang dikaji. Antara lain yaitu pertama pada penelitian yang dilakukan oleh Rachmayani et al., (2017) yaitu tentang snack bar tinggi serat berbahan tepung ampas tahu dan tepung ubi ungu. Kedua Pratama (2019) melakukan penelitian tentang daya terima snack bar rendah energi tinggi serat berbahan dasar tepung mocaf dan tepung kacang merah. Ketiga penelitian yang dilakukan oleh Pratiwi, Sari and Tifauzah (2017) tentang Analisis kadar protein dan kadar serat pada snack bars berbahan campuran tepung cassava dan tepung kacang merah. Dan terakhir penelitian 
yang dilakukan oleh Adiari et al., (2017) tentang pengembangan pangan fungsional berbasis tepung okara dan tepung beras hitam (oryza sativa 1 indica) sebagai makanan selingan bagi remaja obesitas.

Dari beberapa penelitian di atas maka dapat dilihat bahwa sebagian besar bahan utama dalam pembuatan snack bar dengan kandungan serat yang tinggi adalah berbahan dasar tepung kacang merah dan tepung ampas tahu. Akan tetapi tempung ampas tahu komoditasnya sangat jarang ditemukan di daerah NTB sedangkan untuk tepung kacang merah merupakan bahan pangan yang cukup mudah untuk didapatkan di wilayah NTB. Dimana tepung kacang merah mempunyai kandungan serat yang cukup tinggi yaitu per 100 gram kacang merah kering memiliki kandungan serat sebanyak 24 gram, yaitu terdiri dari serat larut air lebih banyak dibandingkan serat yang tidak larut air, oleh karena itu serat kacang merah bisa dengan mudah dimanfaatkan di dalam pengolahan makanan dan tidak menyebabkan perubahan sifat sensori atau orgnoleptik makanan, selain itu kandungan serat pada tepung kacang merah merupkan sumber serat yang baik sehingga dapat memberikan tektur lembut pada nutimat bar (Wiranata et al., 2017).

Pada beberapa penelitian terkait formulasi snack bar tinggi serat diperoleh snack bar dengan sifat organoleptik yang dapat diterima yaitu dihasilkan snack bar dengan warna merah, tesktur rapuh dan tidak melekat serta aroma khas oat dengan sedikit langu. Akan tetapi berdasarkan hasil uji statistik bahwa variasi perlakuan dalam formulasi snack bar ini tidak berpengaruh nyata terhadap kesukaan panelis terhadap aroma dan tekstur snack bar namun berpengaruh nyata terhadap warna dan rasa dari snack bar yang dihasilkan, sehingga perlu dimodifikasi lagi komposisi penambahan setiap bahan agar memiliki pengaruh yang lebih signifikan. Adapun kandungan serat pada snack bar ini tergolong tinggi yaitu sebesar 19,27\% berdasarkan standar kandungan serat SNI cookies dan sudah dapat memenuhi kecukupan serat dari makanan selingan pada dewasa. Penelitian ini dilakukan oleh (Pratama, 2019) tentang Daya terima snack bar tinggi serat berbahan dasar tepung mocaf dan tepung kacang merah dan diperoleh formulasi terbaik adalah pada formula 3 yaitu penambahan tepung campuran (tepung mocaf dan tepung kacang merah) sebanyak 13,5 g.

\section{KESIMPULAN}

Snack bar dengan penambahan tepung beras merah dan tepung jagung serta tepung kacang merah dan buah salak berpengaruh nyata terhadap sifat organoleptik snack bar yang dihasilkan yaitu pada formulasi snack bar Andriani, Ansharullah and Asyik (2018). Dan formulasi snack bar oleh Siregar, Rahmayuni and Noviar (2017). Dengan karakteristik organoleptik snack bar yang dihasikan yaitu dengan warna merah gelap hingga terang, aroma langu khas bahan, rasa khas jagung dan tekstur keras renyah (Andriani, Ansharullah and Asyik (2018)). Serta snack bar dengan warna coklat kekuningan hingga coklat, aroma khas buah salak hingga aroma khas tepung kacang merah, rasa khas buah salak hingga rasa khas kacang merah dan tesktur padat lembut hingga pada kasar (Siregar, Rahmayuni and Noviar (2017))

Ada pengaruh penambahan bahan pangan lokal tepung okara dan tepung beras merah serta tepung kacang merah dan buah salak terhadap kadar serat snack bar yang dihasilkan yaitu pada penelitian Adiari et al., (2017) dan Siregar, Rahmayuni and Noviar, (2017) dengan kandungan serat berturut-turut yaitu 15,58\% dan $8,57 \%$ dimana berdasarkan standar serat pada SNI cookies kandungan serat kedua snack bar tadi tergolong tinggi.

\section{SARAN}

Perlu dilakukan penelitian lebih lanjut tentang snack bar sebagai alternatif jajanan tinggi serat dengan bahan pangan lokal dengan formulasi snack bar yang direkomndasikan yaitu snack bar penelitain (Pratama, 2019).

Perlu dilakukan penelitian lebih lanjut tentang snack bar sebagai alternatif jajanan tinggi serat dengan bahan pangan lokal sebagai pangan fungsional dengan memberikan interfensi kepada penderita obesitas dewasa.

\section{DAFTAR PUSTAKA}

Adiari, N. W. L. et al. (2017) 'Pengembangan pangan fungsional berbasis tepung okara dan tepung beras hitam ( Oryza sativa L . indica ) sebagai makanan selingan bagi remaja obesitas', Jurnal gizi indonesia, 6(1), pp. 51-57.

Andriani, W. O. R. A., Ansharullah and Asyik, N. (2018) 'KARATERISTIK ORGANOLEPTIK DAN NILAI GIZI SNACK BAR BERBASIS TEPUNG BERAS MERAH (Oryza nivara) DAN TEPUNG 
JAGUNG (Zea mays L.) SEBAGAI MAKANAN SELINGAN TINGGI SERAT', Jurnal Sains dan Teknologi Pangan (JSTP), 3(6), pp. 1448-1459.

Arwin, Tamrin, Rahman Baco, A. (2018) 'KAJIAN PENILAIAN ORGANOLEPTIK DAN NILAI GIZI SNACK BAR BERBASIS TEPUNG BERAS MERAH DAN KACANG MERAH (Phaseolus vulgaris L.) SEBAGAI MAKANAN SELINGAN YANG BERSERAT TINGGI', J. Sains dan Teknologi Pangan, 3(2), pp. 1152-1162.

BSN (1992) ‘Standar Mutu Cookies (SNI 01-2973-1992)’, pp. 50-77.

Harikedua, V. T., Legi, N. N. and Sarullah, M. R. (2015) 'DAN STATUS GIZI PADA ANAK SEKOLAH DI SD INPRES BUKU KECAMATAN BELANG’, Gizido, 7(1).

Hendrayati, Manjilala and Islamiati, F. at al. (2019) 'Substitusi bekatul pada pembuatan biskuit terhadap peningkatan kadar serat sebagai jajanan tinggi serat', Media gizi pangan, 26(2), pp. 171-174.

Indrawan, I., Sevelin and Ningrum, indah riski kusuma (2018) 'Pembuatan Snack Bar Tinggi Serat Berbahan Dasar Tepung Ampas Kelapa Dan Tepung Kedelai’, Jurnal ilmiah respati, 9(I), pp. 1-10.

Kusumaningrum, I. and Rahayu, N. S. (2018) 'Formulasi Snack Bar Tinggi Kalium dan Tinggi Serat Berbahan Dasar Rumput Laut, Pisang Kepok, dan Mocaf sebagai Snack Alternatif bagi Penderita Hipertensi', Argipa, 3(2), pp. 102-110.

Marlina, T. R. et al. (2019) 'Makanan Selingan Tinggi Serat Dan Rendah Indeks Glikemik Untuk Penderita Diabetes Melitus Tipe 2', Jurnal riset kesehatan poltekkes kemenkes bandung, 11(2), pp. 51-59.

Pratama, W. (2019) 'Daya Terima Snack BAr Rendah energi Tinggi Serat Berbahan Dasar Tepung Mocaf Dan Tepung Kacang Merah', SSRN Electronic Journal, 5(564), pp. 1-19. doi: 10.4324/9781315853178.

Pratiwi, L. N., Sari, T. and Tifauzah, N. (2017) 'Analisa kadar protein dan kadar serat pada snack bars berbahan campuran tepung cassava dan tepung kacang merah', Skripsi poltekkes kemenkes yogyakarta, pp. $1-79$.

Pricilya, V., W, B. and Andriani, M. (2015) 'Daya Terima Proporsi Kacang Hijau (Phaseolus Radiata L) Dan Bekatul (Rice Bran) Terhadap Kandungan Serat Pada Snack Bar', Media Gizi Indonesia, vol.10, pp. 136140 .

Rachmayani, N. et al. (2017) 'Snack Bar Tinggi Serat Berbasis Tepung Ampas Tahu (Okara) Dan Tepung Ubi Ungu’, Jurnal Teknologi dan Industri Pangan, pp. 139-149. doi: 10.6066/jtip.2017.28.2.139.

Rahmad, A. hendra Al (2019) 'Keterkaitan Asupan Makanan dan Sedentari dengan Kejadian Obesitas Pada Anak Sekolah Dasar di Kota Banda Aceh’, Buletin penelitian kesehatan, pp. 67-76.

Siregar, L. N. S., Rahmayuni and Noviar, H. (2017) 'PEMANFAATAN TEPUNG KACANG MERAH DAN SALAK PANDANG SIDIMPUAN (salacca sumatrana R.) DALAM PEMBUATAN SNACK BAR', Jurnal online mahasiwa fakultas pertanian universitas riau, 36(4), pp. 1-10.

Soeparyo, M. K., Rawung, D. and Assa, J. R. (2018) 'PENGARUH PERBANDINGAN TEPUNG SAGU (Metroxylon sp.) DAN TEPUNG KACANG MERAH (Phaseolus vulgaris L.) TERHADAP SIFAT FISIKOKIMIA DAN ORGANOLEPTIK FOOD BAR', Jurnal teknologi pertanian, 9(2).

Wiranata, I. G. et al. (2017) 'Formulasi dan karakteristik nutrimat bar berbasis tepung kacang kedelai ( glycine max . L ) dan tepung kacang merah ( phaseolus vulgaris . L ) sebagai makanan pasien kemoterapi', Jurnal gizi indonesia, 5(2), pp. 133-139. 